Academic Journal of Plant Sciences 6 (2): 61-63, 2013

ISSN 1995-8986

(C) IDOSI Publications, 2013

DOI: 10.5829/idosi.ajps.2013.6.2.328

\title{
Influence of IBA and NAA on Rooting of Adathoda vasica
}

\author{
T. Susila and G. Satyanarayana Reddy \\ Medicinal and Aromatic Plants Research Station, \\ Dr. YSR Horticultural University Rajendranagar, Hyderabad-500030, India
}

\begin{abstract}
Adathoda vasica is a medicinal plant beneficial for the treatment of asthma, cough, haemorragic disorders, hepatitis and fevers. The leaves of the plant contain a mixture of alkaloid i.e., vasicine and vasicinone. Vasicine has numerous pharmacological activities viz., anti-malarial, anti-inflammatory, antioxidant, antidiabetic, anti-bacterial etc. The study on influence of IBA and NAA on rooting of Adathoda vasica was conducted during 2011-2012 at Medicinal and Aromatic Plants Research Station, Rajendranagar, Hyderabad, India. The experiment was set up in a complete randomized block design with nine treatments (T) consisting of Indole Butyric Acid hormone (IBA) @ 250, 500, 1000 and 1500 ppm; Naphthalene Acetic Acid (NAA) @ 250, $500,1000,1500 \mathrm{ppm}$ and untreated control. These treatments were then designated as T1, T2, T3, T4, T5, T6, T7, T8 and T9, respectively. Results exhibited that maximum rooting percent $(67.50 \%)$ and longest root length (22.18) were recorded in T4 (1500 ppm IBA). Whereas maximum roots per cutting (40.89), root fresh (3.22g) and dry weights $(1.12 \mathrm{~g})$ were noted for T8 (1500 ppm NAA). Thus it can be concluded that if rooting of Adathoda vasica semi hard wood stem cuttings treated with IBA@1500 ppm or NAA@1500 ppm concentration can promote the mass propagation of the said medicinal plant.
\end{abstract}

Key words: Adathoda vasica $\cdot$ Indole Buteric Acid $\cdot$ Naphthalein Acetic Acid

\section{INTRODUCTION}

The plant has been used in the indigenous system of medicine in India for over 2000 years [1]. The plant grows all over the country throught the plains. The root, leaves and flowers of Adathoda vasica are used as medicine, both internally as well as externally. It is beneficial for the treatment of asthma, cough, haemorragic disorders, hepatitis and fevers [2]. The leaves of the plant contain a mixture of alkaloid i.e., vasicine and vasicinone. Vasicine has numerous pharmacological activities viz., anti-malarial [3] anti-imflammatory [4] antioxidant [5] antidiabetic [6] Anti-bacterial [7] etc. The species has gained lot of popularity due to high demand for the medicinal extracts from the leaves. To sustain the demand intensive cultivation and conservation is of most important. The cultivation of Adathoda vasica can easily be carried out if proper vegetative propagation methods have been developed. To support the rapid multiplication of plant material, propagation of Adathoda vasica is viable option. Several research workers used growth regulators to induce rooting of cuttings. Auxins often hasten root initiation, increase the number and percentage of cuttings rooted as well as quality of roots produced per cutting [8]. Larsen and Guse [9] and Kester et al. [10] reported that the most reliable rooting hormone is Indolebutyric acid (IBA) although others such as naphthalene acetic acid (NAA) can also be used. There are reports that it may also be toxic to young/ succulent cuttings of certain species, IBA is still probably the best hormone for general use because of being non-toxic to plants over a wide range of concentration [11]. This study therefore aimed at determining the most appropriate concentration of IBA for propagation of stem cuttings of Adathoda vasica.

\section{METERIALS AND METHODS}

The study was conducted during 2011-2012 at Medicinal and Aromatic Plants Research Station, Rajendranagar, Hyderabad, India. The experiment was set up in a complete randomized design with nine treatments (T) consisting of Indole Butyric Acid hormone (IBA) @ 250, 500, 1000 and 1500 ppm; Naphthalene Acetic Acid

Corresponding Author: T. Susila, Medicinal and Aromatic Plants Research Station, Dr. YSR Horticultural University Rajendranagar, Hyderabad-500030, India. 
(NAA) concentration @ 250, 500,1000, 1500 ppm and untreated control. These nine different treatments were then designated as T1, T2, T3, T4, T5, T6, T7, T8 and T9, respectively. Semi hard wood stem cuttings of $20 \mathrm{~cm}$ long consisting of two or more lateral buds were harvested from Adathoda vasica. Fifty stem cuttings were used in each set of treatment. While preparing the cuttings, a smooth cut was given for each cutting at distal end and slant cut was given at lower end just below lower node. Each set of treated cuttings were then inserted into well prepared beds and replicated three times. The cuttings were treated with different concentrations of IBA and NAA solution by dipping the basal end for 15 minutes. Control cuttings were immersed for the same time in distilled water. The cuttings were maintained in a polyhouse at a day temperature $26 \pm 2{ }^{\circ} \mathrm{C}$, relative air humidity 80 to $90 \%$. Data were recorded on number of cuttings sprouted, number of roots per cutting, length of longest root, root fresh weight and root dry weight. The data were subjected to standard statistical procedures.

\section{RESULTS AND DISCUSSION}

Significant variation was observed between different treatments for percent rooting, number of roots per cutting, length of longest root, root fresh weight and dry weight of Adathoda vasica semi hard wood cuttings (Table 1). The percentage of rooting was highest in IBA 1500 ppm (67.50). However, IBA 250 ppm, IBA 500 ppm, 1000 ppm and NAA 1500 ppm were at par. Percentage of rooting was increased with increase in concentration of IBA and NAA. This could be due to the effect of auxins that have been reported to enhance rooting through the translocation of carbohydrates and other nutrients to the rooting zone [12]. According to Davis and Hassig [13] the production of adventitious roots in plants through cell division, multiplication and specialization is also controlled by plant growth substances especially auxins. This implies that treating stem cuttings with auxins can increase the percentage of rooting, root initiation and number of roots. Even then, application of optimal hormone concentration is very important for successful rooting of cuttings [14]. Lowest percentage of rooting was observed in untreated control (30.75).

Number of roots per cutting were also increased with increase in concentration of IBA and NAA. Highest number of roots per cutting was recorded with NAA 1500 ppm (40.89). Untreated control recorded lowest number of roots per cutting (10.46). Maximum length of root was recorded in IBA $1500 \mathrm{ppm}(22.18 \mathrm{~cm})$. The increase in length of roots in cuttings treated with growth regulators may be due to enhanced hydrolysis of carbohydrates, accumulation of metabolites at the site of application of auxins, synthesis of new proteins, cell enlargement and cell division induced by auxins [15]. The production of adventitious roots in plants is controlled by growth substances, a key role in this process being played by auxins. According to Kralik and Šebanek [16] the correlation had been found in plants between the content of their endogenous auxins and rooting ability. Hence, an exogenous application of synthetic auxins might reinforce the effect of endogenous auxins or directly induced rhizogenesis.

Fresh weight of roots per cutting was highest in NAA 1500 ppm (3.22 g). Lowest weight of root fresh weight was observed in untreated control (1.56 g). Highest dry weight of roots per cutting was recorded in NAA 1500 ppm (1.12 g). Maximum fresh weight and dry weight of roots in Adathoda vasica cuttings treated with

\begin{tabular}{|c|c|c|c|c|c|c|}
\hline \multicolumn{2}{|c|}{ Treatment $(\mathrm{T})$} & \multirow{2}{*}{$\frac{\text { Percent rooting }(\%)}{56.25}$} & \multirow{2}{*}{$\frac{\text { Number of roots/cutting }}{11.00}$} & \multirow{2}{*}{$\frac{\text { Length of longest root }(\mathrm{cm})}{11.71}$} & \multirow{2}{*}{$\frac{\text { Root fresh weight }(\mathrm{g})}{2.16}$} & \multirow{2}{*}{$\frac{\text { Root dry weight }(\mathrm{g})}{0.28}$} \\
\hline $\mathrm{T} 1$ & IBA $250 \mathrm{ppm}$ & & & & & \\
\hline $\mathrm{T} 2$ & IBA 500 ppm & 58.75 & 19.45 & 15.56 & 2.48 & 0.43 \\
\hline $\mathrm{T} 3$ & IBA 1000 ppm & 65.00 & 30.90 & 16.29 & 2.56 & 0.57 \\
\hline $\mathrm{T} 4$ & IBA 1500 ppm & 67.50 & 30.22 & 22.18 & 2.66 & 0.92 \\
\hline T5 & NAA $250 \mathrm{ppm}$ & 43.75 & 21.44 & 16.49 & 2.00 & 0.59 \\
\hline T6 & NAA 500 ppm & 40.00 & 26.00 & 15.36 & 2.37 & 0.67 \\
\hline $\mathrm{T} 7$ & NAA 1000 ppm & 47.50 & 29.89 & 14.38 & 2.81 & 0.89 \\
\hline $\mathrm{T} 8$ & NAA 1500 ppm & 60.00 & 40.89 & 14.50 & 3.22 & 1.12 \\
\hline T9 & IBA $250 \mathrm{ppm}$ & 30.75 & 10.46 & 10.37 & 1.56 & 0.23 \\
\hline \multicolumn{2}{|c|}{$\mathrm{SEm} \pm$} & 6.166 & 2.085 & 1.062 & 0.232 & 0.048 \\
\hline \multicolumn{2}{|c|}{$\mathrm{CD}(0.05)$} & 17.997 & 6.250 & 3.184 & 0.694 & 0.143 \\
\hline
\end{tabular}

$\mathrm{T}=$ Treatments; IBA = Indole Butyric Acid; Naphthalene Acetic Acid; SEm = Standard Error of

Mean and $\mathrm{CD}=$ Critical difference at an $\alpha$ of $5 \%$. 
NAA 1500 ppm could be attributed to highest number of roots produced per cutting. The effect of growth regulators in enhancing root characters of cuttings have been reported by Sherer et al. [17] in different horticultural crops.

\section{CONCLUSIONS}

The production of adventitious roots in plants is controlled by growth substances. Rooting of Adathoda vasica semi hard wood stem cuttings treated with IBA 1500 ppm or NAA 1500 ppm concentration can be promoted for mass propagation.

\section{REFERENCES}

1. Atal, C.K., 1980. Chemistry and Pharmacology of vasicine-A new oxytocic and abortifacient. Regional Research Laboratory, Jammu-Tawi.

2. Paranjpe, P., 2005. Indian Medicinal Plants Forgotten Healers-A guide to Ayurvedic Herbal Medicine. A.K. Lithographers, New Delhi, pp: 278-279.

3. Chopra, R.N., 1955. A Review of Work on Indian Medicinal Plants. Indian Council of Medical Research, New Delhi, pp: 23.

4. Srinivasarao, D., I.A. Jayarraj, R. Jayraaj and M.L. Prabha, 2006. A study on antioxidant and anti-inflammatory activity of vasicine against lung damage in rats. Indian J. Allergy Asthma Immunol., 20(1): 1-7.

5. Padmaja, M., M. Sravanthi and K.P.J. Hemalatha, 2001. Evaluation of antioxidant activity of two Indian medicinal plants. J. Phytol., 3(3): 86-91.

6. Gao, H., Y.N. Huang, B. Gao, P. Li, C. Inagaki and J. Kawabata, 2008. Inhibitory effect on $\alpha$ glucosidase by Adhatoda vasica Nees. Food Chem., 108: 965-972.

7. Ilango, K., V. Chitra, P. Kanimozhi and G. Balaji, 2009. Antidiabetic, antioxidant and antibacterial activities of leaf extracts of Adhatoda zeylanica. Medic (Acanthaceae). J. Pharm. Sci. and Res., 1(2): 67-73.
8. Newton, A.C., J.F. Mesen, J.M.c.P. Dick and R.R.B. Leakey, 1992. Low technology propagation of tropical trees: Rooting physiology and practical implications. In: Mass production technology for genetically improved fast growing forest tree species. AFOCEL, Nangis, France, 2: 417-424.

9. Larsen, F.E. and W.E. Guse, 1997. Propagating deciduous and evergreen shrubs, trees and vines with stem cuttings. A Pacific Northwest Cooperative Extension Publication, Washington, USA, pp: 10.

10. Kester, D.E., T.H. Hartmann and F.T. Davier, 1990. Plant propagation:Principles and Practices. $5^{\text {th }}$ edition. Prentice Hall, Singapore, pp: 647.

11. Chadha, K.L. and B. Choudhury, 1980. Ornamental Horticulture in India. ICAR, New Delhi.

12. Milleton, W., B.C. Jarvis and A. Booth, 1980. The role of auxins in leaves and boron dependant on rooting stem cuttings of Phaseous aureus Roxb. New Phytol., 84: 251-259.

13. Davis, D.T. and B.E. Hassig, 1990. Chemical control of adventitious root formation in cuttings. Bull. Plant Growth Regul. Soc. Am., 18: 1-17.

14. Leakey, R.R.B., V.R. Chapman and K.A. Longman, 1982. Physiological studies for tree improvement and conservation. Some factors affecting root initiation of Triplochiton scleroxylon K. Schum. For. Ecol. Manage., 4: 53-66.

15. Strydem, D.K. and H.T. Hartman, 1960. Effect of indole butyric acid and respiration and nitrogen metabolism in Marianna 2624 plum softwood stem cuttings. Proc. Amer. Soc. Hort., 45(1-2): 81-82.

16. Králik, J. and J. Šebánek, 1980. Effect of growth promoters and inhibitors on rooting of cutting of Populus euroamericana (Dode) Guinier, cultivar Marilandica. Acta Univ. Agric. Brno, A28: 59-70. 12.

17. Sherer, V.K., R.S. Gadiev, A.F. Vorobeva and N.I. Salun, 1985. Growth regulating activity of various chemical compounds of grapevine rootstock cuttings. Vin. Org. Adarsalvai Vinodelie, 28: 12-15. 